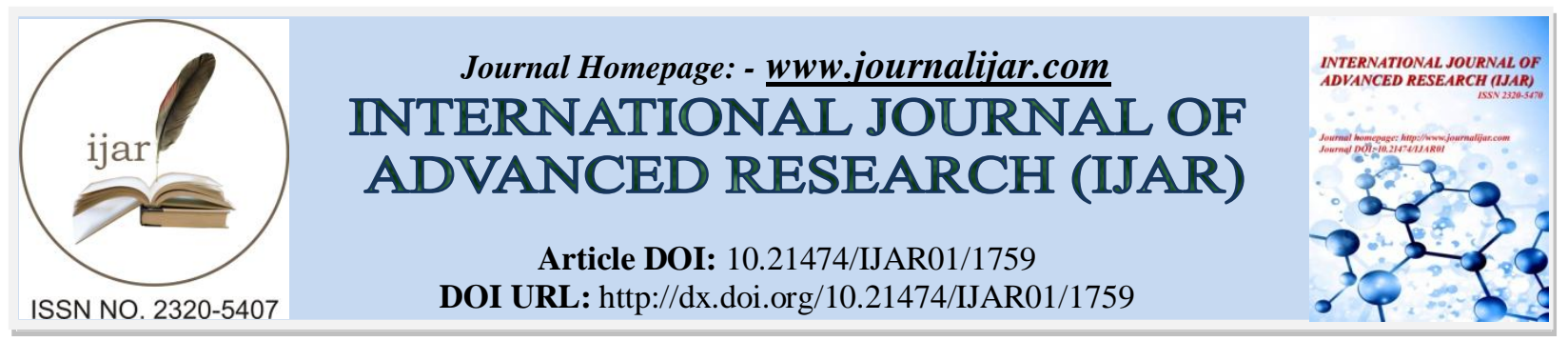

RESEARCH ARTICLE

\title{
VARIATIONS INDUCED IN ELECTROPHORETIC PATTERN OF HAEMOLYMPH PROTEINS OF FLESH FLY, SARCOPHAGA ARGYROSTOMA (DIPTERA: SARCOPHAGIDAE) LARVAE CHALLENGED WITH HYDROGEN PEROXIDE.
}

\author{
S.H. Mahmoud ${ }^{1}$, W.A. Moselhy ${ }^{2}$, L.A.A. El-Khashab ${ }^{2}$, B. Z. Abdelbaset ${ }^{2}$ and A.M. Seufi ${ }^{3}$. \\ 1. Zoology Department, Faculty of Science, Menoufia University, Menoufia, Egypt. \\ 2. Zoology Department, Faculty of Science, Al-Azhar University (Girls branch), Nasr city, Cairo, Egypt. \\ 3. Entomology Department, Faculty of Science, Cairo University, Giza, Egypt.
}

\section{Manuscript Info}

........................

Manuscript History

Received: 12 August 2016

Final Accepted: 22 September 2016

Published: October 2016

\section{Key words:-}

Insect protein, Oxidative stress,

Detoxifying agents, Sarcophaga

argyrostoma, Polyacrylamide gel

electrophoresis, Chemical stressors,

oxidative radicals, protein profile

\section{Abstract}

Insects like all aerobic organisms are continuously exposed to oxidative stress due to products produced during oxygen metabolism and via the metabolism of the encountered toxins including allelochemicals and pesticides. This study was conducted to determine the variation induced in electrophoretic pattern of haemolymph proteins of third instar larvae of flesh fly, Sarcophaga argyrostoma challenged with hydrogen peroxide. Haemolymph was collected every four hours interval for seventy two hours postinjection with hydrogen peroxide. Total soluble protein of the haemolymph was extracted and separated using sodium dodecyl sulphate-polyacrylamide gel electrophoresis (SDS-PAGE). Hydrogen peroxide challenge induced differences in number of electrophoretic protein bands with different molecular weights as compared to control. These results clearly showed that larval challenge with hydrogen peroxide could evoke the haemolymph to synthesize new proteins to overcome such stress. The quantitative analysis also clearly indicated variations in the number as well as intensity of the protein bands.

Copy Right, IJAR, 2016,. All rights reserved.

\section{Introduction:-}

Sarcophagid flies are an important group of dipteran flies because of its medical and veterinary impact (Singh $\boldsymbol{e t}$ al., 2012). Flesh flies have been used as models to study various aspects of insects, such as physiology, biochemistry, development, reproduction and molecular/genetic identification (Wells et al., 2001; Zehner et al., 2004). The flesh flies are also an important family of insects in forensic entomology (Byrd, 1998 \& 2001). Larvae of these flies are closely associated with human and are known to cause animal tissue myiasis. Such severe myiasis caused by this fly, is a grave problem in terms of both the animal welfare and economic loss (Sotiraki et al., 2010). It is known that various chemicals, physical and physiological stressors can result in a stress situation that may upset functional homeostasis which is termed oxidative stress (OS), and is characterized by enhanced production of reactive oxygen species (ROS) with the simultaneous impairment of their scavenging systems. Increased concentrations of ROS result in oxidative damage to proteins, lipids, and nucleic acids, and thus the functions of cells, organs, or the whole organism may be seriously disrupted, leading to death (Kodrik et al., 2015). Hydrogen peroxide, $\mathrm{H}_{2} \mathrm{O}_{2}$ mostly produces ROS as a steady intermediate among all kinds of stressors (Rosa et al., 2008). As an oxidant, $\mathrm{H}_{2} \mathrm{O}_{2}$ can 
regulate the expression of many genes, for instance superoxide dismutase [SODs] (Rhee et al., 2011). High concentrations of $\mathrm{H}_{2} \mathrm{O}_{2}$ can cause severe damage on proteins or DNA, as well initiate lipid peroxidation (Hassan, 1997). Hydrogen peroxide is better known for its cytotoxic effects and it has also become established as an important regulator of eukaryotic signal transduction. Insects are subjected to various environmental stressors that lead to the generation of deleterious reactive oxygen species (Felton, 1995). Oxidative stress reflects the disruption of an intricate balance between the formation and clearance of highly-reactive free radicals in living organisms. The increased production of reactive oxygen species that exceeds the capacities of cellular defense systems leads to oxidative stress in the cell and to the oxidation of proteins, lipids and nucleic acids (Imlay, 2003; Stadtman $\boldsymbol{\&}$ Levine, 2003). Polyacrylamide gel electrophoresis (PAGE) has been extensively used as an excellent tool for the separation of proteins from all living organisms (Zacharius et al., 1969). The vast majority of recent studies on insect proteins have used electrophoretic techniques. Polyacrylamide gel, with the advantages of high sensitivity and resolving power, is generally the most efficient medium to achieve separations from haemolymph samples from single insects (Wyatt \& Pan, 1978). The proteins in insect haemolymph have been separated and in some cases characterized by various workers such as Laufer (1960 a\&b), Loughton \& West (1965), Chen \& Levenbook (1966 a\&b), Adiyodi (1967) and Marty \& Zalta (1967). In the present study, changes in protein profile of haemolymph of $S$. argyrostoma larvae challenged with hydrogen peroxide by SDS- PAGE at different time intervals were investigated.

\section{Materials and methods:- \\ Insect rearing:-}

The stock colony was established from flies originally collected from Faculty of Veterinary Medicine, Cairo University, Giza Governorate by placing a piece of fresh meat in an open wooden box in order to attract gravid females for laying larvae, the larvae were collected, identified and reared to the adult stage. Sarcophaga argyrostoma was maintained in the insectary of Zoology Department, Faculty of Science, Al-Azhar University (girls branch) under laboratory conditions of $\left(25 \pm 1{ }^{\circ} \mathrm{C}, 14 \mathrm{~L}\right.$ : $10 \mathrm{D}$ and $60 \pm 5 \% \mathrm{RH}$. Adults were fed on $10 \%$ sucrose solution while larvae were reared on bovine meat (Bai et al., 1988).

\section{Hydrogen peroxide challenge:-}

Hydrogen peroxide challenge was performed by injecting the newly moulted third instar larvae with $2 \mu 1$ of $30 \%$ hydrogen peroxide using a sterile, thin-needled microsyringe (Kim et al., 2011).

\section{Haemolymph collection:-}

Haemolymph was pooled by cutting off the anterior tip of the larvae with sterile fine scissors. Haemolymph was collected every four hours post injection for three days (5 $\mu \mathrm{l}$ each), in an ice-cold Eppendorf containing few crystals of phenylthiourea to prevent melanization. A haemolymph sample was collected from untreated larvae as control one. All haemolymph samples were preserved in liquid nitrogen till analysis.

\section{Protein extraction and gel preparation:-}

Proteins were extracted from the samples by using Tris buffer system as described by (Dunn, 1993), with $2 \%$ (w/v) [SDS] and 5\% (w/v) 2-mercaptoethanol to cleave the disulphide bonds. The slurry was cooling centrifuged for 20 min. at $12000 \mathrm{rpm}$. The samples were heated in a boiling water bath for 15 minutes before loading to ensure dissociation. Preparation of the gels followed the sodium dodecyl sulphate-polyacrylamide gel electrophoresis (SDS-PAGE) according to the method described by (Laemmli, 1970). Resolving gel (15\%) was used according to (Hames, 1981). Bromophenol blue $(0.001 \%)$ tracking dye was used for marking the buffer front during electrophoresis. The gel was electrophoresed at 25-30 mA constant current, at 200V. Staining was done using Coomassie brilliant blue, and a solution of $10 \%$ acetic acid and $45 \%$ methanol was used for destaining. Protein standards (markers) were used to estimate the molecular weights of the separated bands.

\section{Results:-}

Figures (1-3) and Tables (1-3) illustrated haemolymph proteins of control and treated larvae that electrophoretically separated by SDS-PAGE using $15 \%$ polyacrylamide gel.

The results of protein banding pattern in Fig. 1 and Table 1 showed that the treated haemolymph at 4,8 and $12 \mathrm{~h}$ post injection had the same protein bands of the untreated haemolymph with more or less increased intensity of some bands. The molecular weights of separated protein bands were 205.127, 198.886, 137.462, 79.604, 64.122, 
$60.279,58.336,56.123,54.789,52.322,50.125,48.203,46.683,44.763,40.113,38.234,33.987,28.356,26.115$ and $11.234 \mathrm{kDa}$. Bands 1, 4, 6, 7, 8, 9, 10, 11, 12, 13 and 17 appeared in haemolymph of both control and all hydrogen peroxide-challenged larvae, while bands 2, 3, 5, 18 and 20 were observed at all treated samples and disappeared at $16 \mathrm{~h}$ p.i. Bands 14, 15, 16 and 19 were detected in hydrogen peroxide-challenged larvae at 4, 8 and $12 \mathrm{~h}$ p.i. and disappeared at 16, 20, and $24 \mathrm{~h}$ post injection. At 16, 20 and $24 \mathrm{~h}$ p.i., there was a unique band with molecular weight of $39.245 \mathrm{kDa}$ and not observed in both control and other treated samples. Another unique band with molecular weight of $15.921 \mathrm{kDa}$., appeared only at 16, 20 and $24 \mathrm{~h}$ p.i.

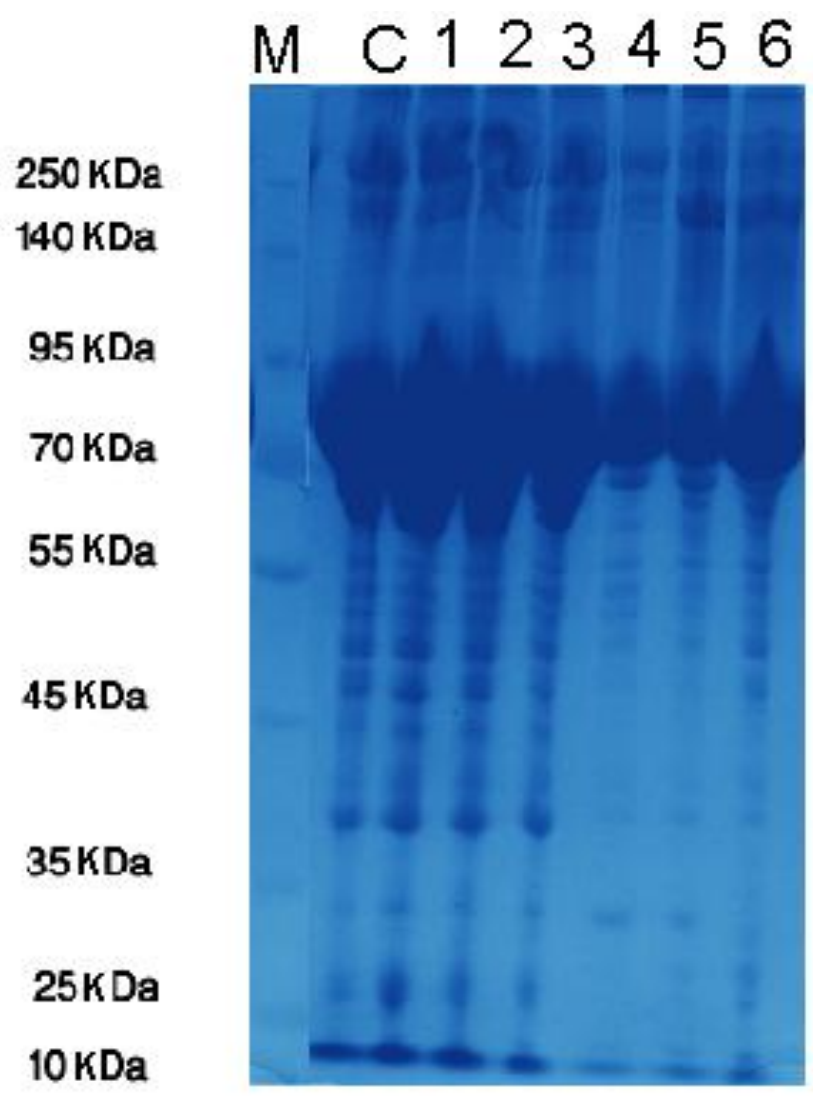

Fig. 1:- Changes in haemolymph protein banding patterns of third larval instar of S. argyrostoma challenged by hydrogen peroxide using SDS-PAGE. Lane M: Marker, C: control and lanes 1-6: treated larvae at 4, 8, 12, 16, 20 and $24 \mathrm{~h}$ post injection. 
Table 1:- The molecular weight analysis of haemolymph proteins of third larval instar of S. argyrostoma challenged by hydrogen peroxide using SDS-PAGE. LaneM: Marker, C :control and L1-L6 treated larvae at 4, 8, 12, 16, 20 and $24 \mathrm{~h}$ post injection.

\begin{tabular}{|c|c|c|c|c|c|c|c|c|}
\hline$M$ & $\begin{array}{c}\text { Number of } \\
\text { band }\end{array}$ & $\mathrm{C}$ & L 1 & L 2 & L 3 & L 4 & L 5 & L 6 \\
\hline \multicolumn{9}{|l|}{250} \\
\hline & 1 & 205.127 & 205.127 & 205.127 & 205.127 & 205.127 & 205.127 & 205.127 \\
\hline & 2 & 198.886 & 198.886 & 198.886 & 198.886 & - & 198.886 & 198.886 \\
\hline \multicolumn{9}{|l|}{140} \\
\hline & 3 & 137.462 & 137.462 & 137.462 & 137.462 & - & 137.462 & 137.462 \\
\hline \multicolumn{9}{|l|}{95} \\
\hline & 4 & 79.604 & 79.604 & 79.604 & 79.604 & 79.604 & 79.604 & 79.604 \\
\hline \multicolumn{9}{|l|}{70} \\
\hline & 5 & 64.122 & 64.122 & 64.122 & 64.122 & - & 64.122 & 64.122 \\
\hline & 6 & 60.279 & 60.279 & 60.279 & 60.279 & 60.279 & 60.279 & 60.279 \\
\hline & 7 & 58.336 & 58.336 & 58.336 & 58.336 & 58.336 & 58.336 & 58.336 \\
\hline & 8 & 56.123 & 56.123 & 56.123 & 56.123 & 56.123 & 56.123 & 56.123 \\
\hline \multicolumn{9}{|l|}{55} \\
\hline & 9 & 54.789 & 54.789 & 54.789 & $\begin{array}{l}54.789 \\
\end{array}$ & 54.789 & 54.789 & 54.789 \\
\hline & 10 & 52.322 & 52.322 & 52.322 & 52.322 & 52.322 & 52.322 & 52.322 \\
\hline & 11 & 50.125 & 50.125 & 50.125 & 50.125 & 50.125 & 50.125 & 50.125 \\
\hline & 12 & 48.203 & 48.203 & 48.203 & 48.203 & 48.203 & 48.203 & 48.203 \\
\hline & 13 & 46.683 & 46.683 & 46.683 & 46.683 & 46.683 & 46.683 & 46.683 \\
\hline \multicolumn{9}{|l|}{45} \\
\hline & 14 & 44.763 & 44.763 & 44.763 & 44.763 & - & - & - \\
\hline & 15 & 40.113 & 40.113 & 40.113 & 40.113 & - & - & - \\
\hline & & & & & & 39.245 & 39.245 & 39.245 \\
\hline & 16 & 38.234 & 38.234 & 38.234 & 38.234 & - & - & - \\
\hline \multicolumn{9}{|l|}{35} \\
\hline & 17 & 33.987 & 33.987 & 33.987 & 33.987 & 33.987 & 33.987 & 33.987 \\
\hline & 18 & 28.356 & 28.356 & 28.356 & 28.356 & - & 28.356 & 28.356 \\
\hline & 19 & 26.115 & 26.115 & 26.115 & 26.115 & - & - & - \\
\hline \multicolumn{9}{|l|}{25} \\
\hline & & & & & & 15.921 & 15.921 & 15.921 \\
\hline & 20 & 11.234 & 11.234 & 11.234 & 11.234 & - & 11.234 & 11.234 \\
\hline 10 & & & & & & & & \\
\hline
\end{tabular}

Figure 2 and Table 2 illustrated the protein banding pattern of the haemolymph at 28, 32, 36, 40, 44 and $48 \mathrm{~h}$ post injection compared to marker and the untreated haemolymph. It was obvious that the treated samples had somewhat different numbers of bands ranging from 20 to 12 bands. The same twenty bands were present in control larvae, and $32 \mathrm{~h}$ post injection. The bands $4,12,13,15,16,19$ and 20 were not affected with treatment and appeared in all lanes, while drastic changes happened at 40,44 and $48 \mathrm{~h}$ post injection that several protein bands of untreated haemolymph disappeared after these periods of injections. On the other hand a unique protein band with molecular weight $129.214 \mathrm{kDa}$ was observed in the haemolymph at 40 and $44 \mathrm{~h}$ post injection. 


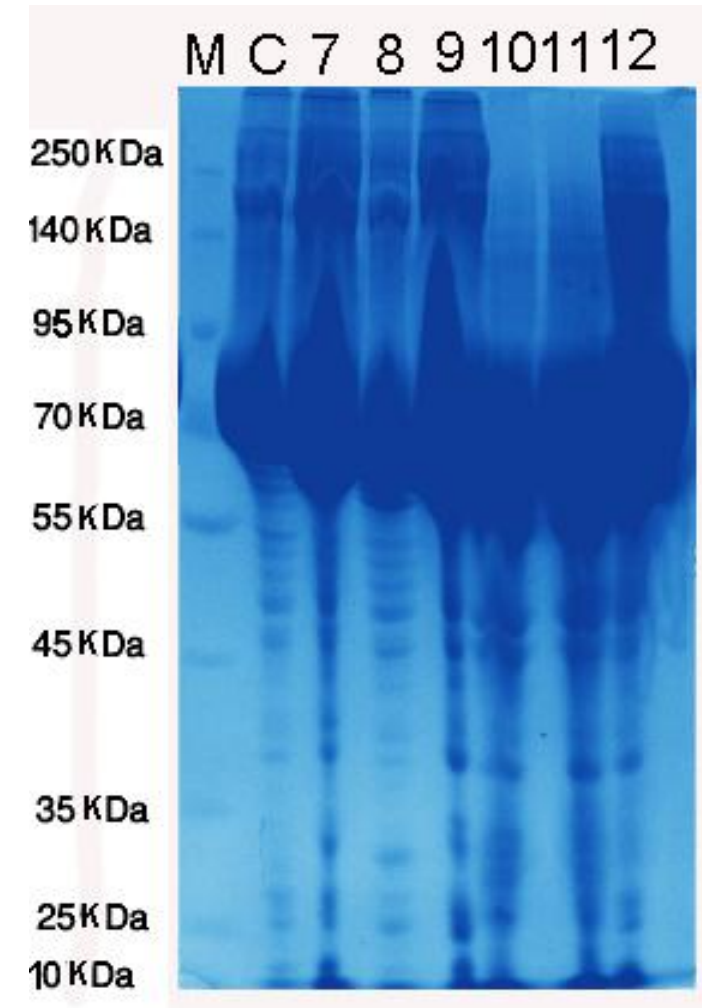

Fig. 2:- Changes in haemolymph protein banding patterns of third larval instar of $S$. argyrostoma challenged by hydrogen peroxide using SDS-PAGE. LaneM: Marker, C :control and lanes 7-12 treated larvae at 28, 32, 36, 40, 44 and $48 \mathrm{~h}$ post injection. 
Table 2:- The molecular weight analysis of haemolymph proteins of third larval instar of S. argyrostoma challenged by hydrogen peroxide using SDS-PAGE. LaneM: Marker, C :control and lanes L7- L12 treated larvae at 28, 32, 36, 40, 44 and $48 \mathrm{~h}$ post injection.

\begin{tabular}{|c|c|c|c|c|c|c|c|c|}
\hline M & $\begin{array}{l}\text { Number } \\
\text { of band }\end{array}$ & $\mathrm{C}$ & L 7 & L 8 & L 9 & L 10 & L 11 & L 12 \\
\hline \multicolumn{9}{|l|}{250} \\
\hline & 1 & 205.127 & 205.127 & 205.127 & 205.127 & - & - & 205.127 \\
\hline & 2 & 198.886 & 198.886 & 198.886 & 198.886 & - & - & 198.886 \\
\hline \multicolumn{9}{|l|}{140} \\
\hline & 3 & 137.462 & 137.462 & 137.462 & 137.462 & 137.462 & 137.462 & 137.462 \\
\hline & & - & - & - & - & 129.214 & 129.214 & 129.214 \\
\hline \multicolumn{9}{|l|}{90} \\
\hline & 4 & 79.604 & 79.604 & 79.604 & 79.604 & 79.604 & 79.604 & 79.604 \\
\hline \multicolumn{9}{|l|}{70} \\
\hline & 5 & 64.122 & - & 64.122 & - & - & - & - \\
\hline & 6 & 60.279 & - & 60.279 & - & - & - & - \\
\hline & 7 & 58.336 & - & 58.336 & - & - & - & - \\
\hline & 8 & 56.123 & - & 56.123 & - & - & - & - \\
\hline \multicolumn{9}{|l|}{55} \\
\hline & 9 & 54.789 & 54.789 & 54.789 & 54.789 & - & - & - \\
\hline & 10 & 52.322 & 52.322 & 52.322 & 52.322 & - & - & - \\
\hline & 11 & 50.125 & 50.125 & 50.125 & 50.125 & - & - & - \\
\hline & 12 & 48.203 & 48.203 & 48.203 & 48.203 & 48.203 & 48.203 & 48.203 \\
\hline & 13 & 46.683 & 46.683 & 46.683 & 46.683 & 46.683 & 46.683 & 46.683 \\
\hline \multicolumn{9}{|l|}{45} \\
\hline & 14 & 44.763 & 44.763 & 44.763 & 44.763 & - & - & 44.763 \\
\hline & 15 & 40.113 & 40.113 & 40.113 & 40.113 & 40.113 & 40.113 & 40.113 \\
\hline & 16 & 38.234 & 38.234 & 38.234 & 38.234 & 38.234 & 38.234 & 38.234 \\
\hline \multicolumn{9}{|l|}{35} \\
\hline & 17 & 33.987 & 33.987 & 33.987 & 33.987 & 33.987 & 33.987 & - \\
\hline & 18 & 28.356 & 28.356 & 28.356 & 28.356 & - & - & 28.356 \\
\hline & 19 & 26.115 & 26.115 & 26.115 & 26.115 & 26.115 & 26.115 & 26.115 \\
\hline \multicolumn{9}{|l|}{25} \\
\hline & & - & 24.127 & & 24.127 & 24.127 & 24.127 & 24.127 \\
\hline & & - & 15.921 & & 15.921 & 15.921 & 15.921 & - \\
\hline & 20 & 11.234 & 11.234 & 11.234 & 11.234 & 11.234 & 11.234 & 11.234 \\
\hline 10 & & & & & & & & \\
\hline
\end{tabular}

The variations that were observed at 40, 44 and $48 \mathrm{~h}$ post injection changed on the third day of treatment (Fig. 3 and Table 3). Most of disappeared protein bands were observed again at 52, 56, 60 and $64 \mathrm{~h}$ post injection, while some of these bands disappeared again at 68 and $72 \mathrm{~h}$ post injection. Another unique protein band with molecular weight $39.154 \mathrm{kDa}$ was observed at $72 \mathrm{~h}$ post injection. It was clear from the overall results of SDS-PAGE that larvae challenged with hydrogen peroxide could evoke the haemolymph to synthesise new proteins. 


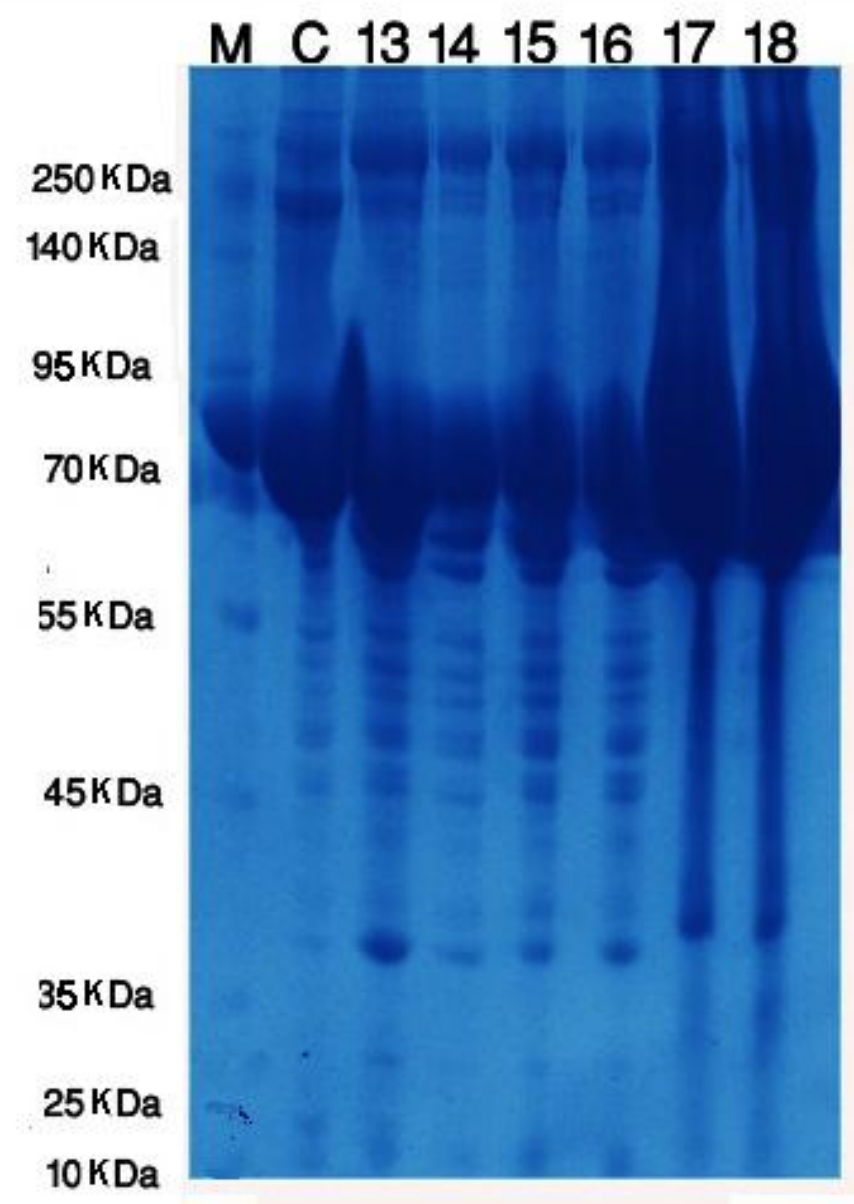

Fig . 3:- Changes in haemolymph protein banding patterns of third larval instar of S. argyrostoma challenged by hydrogen peroxide using SDS-PAGE. LaneM: Marker,C :control and lanes 13-18 treated larvae at 52,56, 60, 64, 68 and $72 \mathrm{~h}$ post injection. 
Table 3:- The molecular weight analysis of haemolymph proteins of third larval instar of $S$. argyrostoma challenged by hydrogen peroxide using SDS-PAGE. LaneM: Marker, C :control and lanes L13- L18 treated larvae at 52,56, 60, 64, 68 and $72 \mathrm{~h}$ post injection.

\begin{tabular}{|c|c|c|c|c|c|c|c|c|}
\hline M & $\begin{array}{c}\text { Number of } \\
\text { band }\end{array}$ & $\mathrm{C}$ & L 13 & L 14 & L 15 & L 16 & L 17 & L 18 \\
\hline \multicolumn{9}{|l|}{250} \\
\hline & 1 & 205.127 & 205.127 & 205.127 & 205.127 & 205.127 & 205.127 & 205.127 \\
\hline & 2 & 198.886 & 198.886 & 198.886 & 198.886 & 198.886 & 198.886 & 198.886 \\
\hline \multicolumn{9}{|l|}{140} \\
\hline \multirow[t]{2}{*}{95} & 3 & 137.462 & 137.462 & 137.462 & 137.462 & 137.462 & 137.462 & 137.462 \\
\hline & 4 & 79.604 & 79.604 & 79.604 & 79.604 & 79.604 & 79.604 & 79.604 \\
\hline \multicolumn{9}{|l|}{70} \\
\hline & 5 & 64.122 & 64.122 & 64.122 & 64.122 & 64.122 & & \\
\hline & 6 & 60.279 & 60.279 & 60.279 & 60.279 & 60.279 & 60.279 & 60.279 \\
\hline & 7 & 58.336 & & & & & & \\
\hline & 8 & 56.123 & - & & & & & \\
\hline \multicolumn{9}{|l|}{55} \\
\hline & 9 & 54.789 & 54.789 & 54.789 & 54.789 & 54.789 & & \\
\hline & 10 & 52.322 & 52.322 & 52.322 & 52.322 & 52.322 & & \\
\hline & 11 & 50.125 & 50.125 & 50.125 & 50.125 & 50.125 & & \\
\hline & & & 49.211 & 49.211 & 49.211 & 49.211 & & \\
\hline & 12 & 48.203 & 48.203 & 48.203 & 48.203 & 48.203 & & \\
\hline & & & 47.120 & - & 47.120 & 47.120 & & \\
\hline & 13 & 46.683 & 46.683 & - & 46.683 & 46.683 & & \\
\hline \multicolumn{9}{|l|}{45} \\
\hline & 14 & 44.763 & 44.763 & 44.763 & 44.763 & 44.763 & & \\
\hline & 15 & 40.113 & 40.113 & 40.113 & 40.113 & 40.113 & & \\
\hline & & & & & & & 39.154 & 39.154 \\
\hline & 16 & 38.234 & 38.234 & 38.234 & 38.234 & 38.234 & & \\
\hline \multicolumn{9}{|l|}{35} \\
\hline & 17 & 33.987 & 33.987 & 33.987 & 33.987 & 33.987 & 33.987 & 33.987 \\
\hline & 18 & 28.356 & 28.356 & 28.356 & 28.356 & 28.356 & 28.356 & 28.356 \\
\hline & 19 & 26.115 & 26.115 & 26.115 & 26.115 & 26.115 & 26.115 & 26.115 \\
\hline \multicolumn{9}{|l|}{25} \\
\hline & & & 24.127 & 24.127 & 24.127 & 24.127 & 24.127 & 24.127 \\
\hline & 20 & 11.234 & 11.234 & 11.234 & 11.234 & 11.234 & 11.234 & 11.234 \\
\hline 10 & & & & & & & & \\
\hline
\end{tabular}

\section{Discussion:-}

Protein is necessary for various biological activities during development, metamorphosis and maintenance of various physiological functions in different tissues (Kumar et al., 2011). The various aspects of protein metabolism including quantitative changes in haemolymph protein synthesis and metabolic activity of specific enzymes have attracted the interest of many insect biochemists. The proteins play an important role in the haemolymph of insects not only in specific transport functions, but also in their enzyme action. The synthesis and utilisation of haemolymph proteins are controlled by genetic and hormonal factors (Hurlimann et al., 1974). Proteins could be antibacterial agents (Riddiford et al., 1983), detoxifying agents (Furukawa et al., 1999), hormone carriers (Fengwu et al., 1997), morphogenesis proteins (Kiheung et al., 1998) or even similar to some human proteins. As the haemolymph composition of the insects reflects the nature and degree of metabolism of the tissue suffused in this fluid, changes in the proteins of the haemolymph may show the level of modification in the organism. The qualitative variations in the protein bands of different treatments and in different days during the larval life indicate both utilities of the specific proteins as well as the synthesis of new proteins by the insect (Lokesh et al., 2006). Results obtained from the SDS-PAGE of haemolymph of $\mathrm{H}_{2} \mathrm{O}_{2}$-challenged larvae at different time intervals demonstrated that there were 
changes in the protein pattern of the challenged larvae as compared to control. Thus, $\mathrm{H}_{2} \mathrm{O}_{2}$ was capable of changing the profiles of haemolymph proteins qualitatively. The appearance of different bands in challenged larvae may be attributed to the induction of new proteins. The synthesis of new proteins may be a result of simultaneous induction of challenging with hydrogen peroxide. Such change in protein profile between normal and challenged larvae may be attributed to the increased production of antioxidants and repair proteins that allow adaptation to these oxidative conditions (Storz \& Tartaglia, 1992; Jamieson, 1998) and may reflect specialization and adaptation in the organisms based on subtle metabolic alterations (Witmore \& Gilbert, 1974). Total protein changes and the electrophoretic protein bands studies in insects after various treatments were recorded by many authors (Latha $\boldsymbol{e t}$ al., 1996; Zidan et al., 1996; Chau faux et al., 1997; Kawaski, 1998; Salama et al., 1999). Till now there have not been any published reports regarding variations induced in protein profiles of Sarcophaga sp following hydrogen peroxide challenge. However, some studies are available with other chemical and physical stressors. The present results agreed with Amin (2010) who determined the variation induced in electrophoretic protein pattern of first and third instar larvae of flesh fly, S. bullata irradiated with Gamma rays (physical stressor) comparing with unirradiated larvae and found that the challenging with radiation resulted in appearance of unique protein bands in the treated sample by using SDS-PAGE and disappearance of protein bands as compared with control. Also, Bedenarova $\boldsymbol{e t} \boldsymbol{a l}$. (2013) investigated injection of hydrogen peroxide into the body of adult female Pyrrhocoris apterus (Heteroptera: Pyrrhocoridae) and noticed a highly significant increase in protein carbonyl levels and AKH titres: 2.8 -fold in CNS and 3.8-fold in haemolymph compared with controls. Changes in protein profiles of insect larvae subjected to different chemical and physical stressors were investigated in Heliothis zea (Vinson \& Lewis, 1969) and Pieris brassicae (Bai \& Degheele, 1988). Omar et al. (2005) reported that (SDS-PAGE) analysis of greater wax moth (Galleria mellonella) infected with B. thuringinsis showed four peptide groups in the range of 11- $120 \mathrm{kDa}$. ElShiekh et al. (2010) found that the protein profiles of $S$. littoralis treated with five profenofos formulations, after stored at cold and hot conditions, were differently changed and distinguished into several separated protein bands in the range of 3.6 to $195.5 \mathrm{kDa}$. It can be concluded that the proteins play an important role in the haemolymph of insects not only in specific transport functions, but also in their enzyme and hormone action as antibacterial agents or detoxifying agents. This conclusion was reinforced by Ahmad (1992) who reported that oxidative stress may lead to membrane or the whole cell damage by lipid peroxidation and protein oxidation resulting in uncontrolled apoptosis. Eukaryotes, including insects, possess a suite of antioxidant enzymes that protects their cells from oxidative radicals.

\section{References:-}

1. Adiyodi, K.G. 1967. The nature of haemolymph proteins in relation to the ovarian cycle in the viviparous cockroach, Nauphoeta cinerea. Journal of Insect Physiology 13: 1189-1195.

2. Ahmad, S. 1992. Biochemical defense of pro-oxidant plant allelochemicals by herbivorous insects. Biochemical System and Ecology 20: 269-296.

3. Amin, M.M. 2010. Electrophoretic protein pattern of the flesh fly, Sarcophaga bullata larvae untreated and treated with gamma radiation. Journal of Radiation Research and Application Science 3: 677 -689.

4. Bai, C. and Degheele, D. 1988. Characterization of the gut juce and haemolymp proteins of Mamestra brassicae L., Pieris brassicae L. and Spodoptera littoralis (Boisd) larvae and susceptibility to Bacillus thuringiensis var. thuringiensis crystal toxins. Mededelingen van de Faculteit landbouwwetenschappen, Rijksuniversiteit Gent 53(1): 255-259.

5. Bedenarova, A., Krisnan, N.J., Cheng, I-C., Vecera, J., Lee, H.J. and Kodrik, D.R. 2013. Adipokinetic hormone counteracts oxidative stress elicited in insects by hydrogen peroxide: in vivo and in vitro study. Physiological Entomology 38: 54-62

6. Byrd, J.H. and Butler, J.F. 1998. Effects of temperature on Sarcophaga haemorrhoidalis (Diptera: Sarcophagidae) development. Journal of Medical Entomology 35: 694-698.

7. Byrd, J.H. and Castner, J.L. 2001. Forensic entomology: utility of arthropods in legal investigation. CRC, Boca. Raton. 43-80.

8. Chau faux , J., Marchal, M., Gilois, N., Jehanno, I. and Buisson, C. 1997. Research into natural sources of Bacillus Thuringiensis in different biotopes, across the world. Canadian Journal of Microbiology 43 (4): 337 343.

9. Chen, P.S. and Levenbook, L. 1966a. Studies on the haemolymph proteins of the blowfly Phormia regina-I. Changes in ontogenetic patterns. Journal of Insect Physiology 12: 1595-1609

10. Chen, P.S. and Levenbook, L. 1966b. Studies on the haemolymph proteins of the blowfly Phormia regina--II. Synthesis and breakdown as revealed by isotopic labelling. Journal of Insect Physiology 12: 1611-1627.

11. Dunn, M.J. 1993. Gel Electrophoresis Protein. Bios Sientific Publishers . 51-53. 
12. El-Shiekh, Y. W. A., Karima, H. E. Haggag and Olfat, A. Radwan. 2010. Comparative studies among trade Profenofos insecticides using physical, chemical and biological parameters. American-Eurasian Journal of Agricultural. and Environmental Science 8(4): 370-282.

13. Felton, G.W. 1995. Antioxidant defenses of vertebrates and invertebrates. In: Ahmad, S. (Ed.), Oxidative Stress and Antioxidant Defenses in Biology. 356-434. Chapman and Hall, New York, U.S.A..

14. Fengwu, L., Pengwen, W., Binghul, Y., Fw, L., Pw, W. and Bh, Y. 1997 . Analysis of electropherograms of proteins in larvae and hemolymph of Anopheles stephensi and A. anthropophagus treated with alphapermethrin chin. Journal of Vector Biology and Control 8: 260-263.

15. Furukawa, S., Tanaka, H., Nakazawa, H., Ishibashi, L., Shono, T. and Yamakawa, M. 1999. Inducible gene expression of moricin a unique antibacterial peptide from the silkworm (Bombyx mori). Biochemical Journal 340: 265-271, London.

16. Hames, B.D. 1981. An introduction to polyacrylamide gel electrophoresis. A Practical Approach. IRL Press. 1 - 91. Oxford, U.K.

17. Hassan, H.M. 1997. Cytotoxicity of Oxyradicals and the evolution of Superoxide dismutase. In Clerch LB, Massaro DJ, eds. Oxygen, Gene Expression, and Cellular Function. 27 - 47. Marcel Dekker, Inc , NewYork

18. Hurlimann, R.F. and Chen, P.S. 1974. Ontogenetische veranderungen des enzymmusters in der haemolymphe von Phormia rigina. Revue suisse de zoologie 81: 648-6.

19. Imlay, J. A. 2003. Pathways of oxidative damage. Annual Review of Microbiology 57: 395-418.

20. Jamieson, D.J. 1998. Oxidative stress responses of the yeast Sacharomyces cerevisiae. Yeast 14: 1511-1527.

21. Kawaski, H. 1998. Transition from larvae to pupa morphogenesis, cell proliferation and protein synthesis in Bombyx wing disc. Invertebrate Reproduction \& Development 34: 101-108.

22. Kiheung, A., Sanghak, J., Kyungro, L., KH, A., SH, J. and KR, L. 1998. Purification and characterization of a juvenile hormone bindingprotein from whole body homogenates of the wax moth Galleria mellonella final instar larvae. Korean Journal of Biological Sciences. 71-75.

23. Kim, B.Y., Hiu, W.L., Lee, K.S., Wan, H., Yoon, H.J., Gui, Z.Z., Chen, S. and Jin, B.R. 2011. Molecular cloning and oxidative stress response of a sigmaclass glutathione S-transferase of the bumblebee Bombus ignites. Comparative Biochemistry and Physiology 158: 83-89

24. Kodrík, D., Bednářová, A., Zemanová, M. and Krishnan, N. 2015. Hormonal Regulation of Response to Oxidative Stress in Insects-An Update . International Journal of Molecular Sciences 16: 25788 - 25816

25. Kumar, D., Pandey, J. P., Jain, J., Mishra, P. K., and Prasad, B. C. 2011. Qualitative and quantitative changes in protein profile of various tissues of tropical tasar silkworm, . Antheraea mylitta Drury. International Journal of Zoological Research 7: 147-155

26. Laemmli, U.K. 1970. Cleavage of structural proteins during the assembly of the head bacteriophaga T4. Nature 22: $680-685$.

27. Latha, E.S., Krishnayya, P.V. and Subbaratnam, G. V. 1996. Effect of Bacillus thruingiensis var kurstaki Berliner and its addative chemicalson haemolymp. Constituents of Spodoptera litura (Fab). Pest Management \& Economic Zoology 4 (1-2): 65-69.

28. Laufer, H. 1960a. Blood proteins in insect development. Annals of the New York Academy of Sciences 89: 490-515.

29. Laufer, H. 1960b. Studies of changes in enzymatic activities of blood proteins in the developing silk moth: Proc. 11 th Int. Cong. Ent 3: 194-200.

30. Lokesh, G, Narayanaswamy, M. and Ananthanarayana, S . R. 2006. The Effect of chemical mutagen on haemolymph proteins of silkworm, Bombyx mori L. (Lepidoptera: Bombycidae) in F1 stage. Journal of Applied Science \& Environmental Management 10 (3): 21 - 25.

31. Loughton, B . G. and West, A. S. 1965. The development and distribution of haemolymph proteins in Lepidoptera. Journal of Insect Physiology 11: 919-932.

32. Marty, R. and Zalta, J. P. 1967. Variations intraspCcifiques qualitatives et quantitative des protCines de l'h\&molymphe de Cophopodisma pyrenae (Orthoptera, Catantopidae) en fonction des aires biographiques. Académie des sciences 264: 643-646

33. Omar, A. M., Naglaa, M. M. El-Husseini,. and El-Bishry, M. H. 2005. Protein patterns in larvae of the greater wax month, Galleria mellonella L., induced by Bacillus thuringiensis kurstaki. Egyptian Journal of Biological Pest Control 15(1): 71-75.

34. Rhee, J.S., Kim, R.O., Choi, H.G., Lee, J., Lee, Y.M. and Lee, J.S. 2011. Molecular and biochemical modulation of heat shock protein 20 (Hsp20) gene by temperature stress and hydrogen peroxide (H2O2) in the monogonont rotifer, Brachionus sp. Comparative Biochemistry and Physiology 154: 19-27. 
35. Riddiford, L.M. and Law, J.H. 1983. Larval Serum proteins of Lepidoptera. In : Scheller K,editors. The larval serum proteins of insects function, biosynthesis, genetics. 5-85.

36. Rosa, C.E., Bianchini, A. and Monserrat, J.M. 2008. Antioxidant responses of Laeonereis acuta (Polychaeta) after exposure to hydrogen peroxide. Brazilian Journal of Medical \& Biological Research 41: 117-121.

37. Salama, H.S., El-Moursy, A.A. and Abdel-Rahman, A. M. 1999. Changes in the chemistry of the haemolymph of the corn borers Chilo agamemnom (Carambidae) and Ostrinia nubilalis (Pyraustidae) after treatment with Bacillus thuringiensis. Archives of Phytopathology and Plant Protection 32(3): 249-256.

38. Singh, K. and Thakur S. 2012. Electrophoretic Characterization of Sanitarily and Medically important Flesh Fly, Sarcophaga dux (Diptera, Sarcophagidae)Using Isozymes. National Academy of Science 35:339-342 Sotiraki ,S., Farkasb, R. and Hallc, M.J. 2010. Flesh flies in the flesh: epidemiology, population genetics and control of outbreaks of traumatic myiasis in the Mediterranean Basin. Veterinary. Parasitology 174: 12-18.

39. Stadtman, E.R. and Levine, R.L. 2003. Free radical-mediated oxidation of free amino acids and amino acid residues in proteins. Amino Acids 25: 207-218.

40. Storz, G. and Tartaglia, L.A. 1992. OxyR: a regulator of antioxidant genes. Journal of Nutrition 122: 627-630.

41. Vinson, S. B. and Lewis, W. J. 1969. Electrophoretic study of protein changes between several developmental stages of three species of Heliothis. Comparative Biochemistry and Physiology 28: 215 - 220.

42. Wells, J.D., Pape, T. and Sperling, F.A.H. 2001. DNA-based identification and molecular systematics of forensically important Sarcophagidae (Diptera). Journal of Forensic Science 46: 1098- 1102.

43. Whitmore, E. and Gilbert, L.I. 1974. Haemolymph protein and Lipoproteins In Lepidoptera-Acomparative electrophoretic study. Comparative Biochemistry and Physiology 47B: 63-78.

44. Wyatt, G. R. and Pan, M. L. 1978 . Insect plasma proteins. Annual Review of Biochemistry 47: 779-817.

45. Zacharius, R.M., Zell, T. E., Morrison, J.H. and Woodlock, J. J. 1969. Glycoprotein Staining Following electrophoresis on acrylamide gel. Analytical Biochemistry 30: 148-152.

46. Zehner, R., Amendt, J., Schutt,S., Sauer, J., Krettek, R. and Povolny, D. 2004. Genetic identification of forensically important flesh flies(Diptera: Sarcophagidae). International Journal of Legal Medicine 118: 245-247

47. Zidan ,Z. H., Moawad, G. M., Gadallah, A. I. and El-Sweeki, F. E. 1996. Biochemical aspects of the cotton leaf worm Spodoptera littoralis (Boisd). Annals of Agricultural Science. 233 -244. Special Issue, Cairo. 